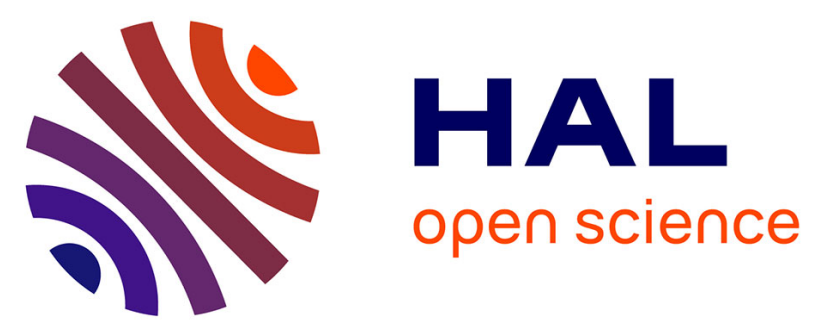

\title{
Surface water linkages regulate trophic interactions in a groundwater food web
}

\author{
Arnaud Foulquier, Florian Malard, Florian Mermillod-Blondin, Bernard \\ Montuelle, Sylvain Dolédec, Bernadette Volat, Janine Gibert
}

\section{To cite this version:}

Arnaud Foulquier, Florian Malard, Florian Mermillod-Blondin, Bernard Montuelle, Sylvain Dolédec, et al.. Surface water linkages regulate trophic interactions in a groundwater food web. Ecosystems, 2011, 14 (8), pp.1339-1353. 10.1007/s10021-011-9484-0 . halsde-00667327

\section{HAL Id: halsde-00667327 https://hal.science/halsde-00667327}

Submitted on 15 May 2020

HAL is a multi-disciplinary open access archive for the deposit and dissemination of scientific research documents, whether they are published or not. The documents may come from teaching and research institutions in France or abroad, or from public or private research centers.
L'archive ouverte pluridisciplinaire HAL, est destinée au dépôt et à la diffusion de documents scientifiques de niveau recherche, publiés ou non, émanant des établissements d'enseignement et de recherche français ou étrangers, des laboratoires publics ou privés. 
Running head: Regulation of groundwater food webs

Surface water linkages regulate trophic interactions in a groundwater food web

ARNAUD FOULQUIER ${ }^{1, *}$, FLORIAN MALARD ${ }^{1}$, FLORIAN MERMILLOD-

BLONDIN $^{1}$, BERNARD MONTUELLE $^{2}$, SYLVAIN DOLEDEC $^{1}$, BERNADETTE

VOLAT $^{2}$ and JANINE GIBERT ${ }^{1}$

${ }^{1}$ Université de Lyon, Lyon, F-69622, France ; Université Lyon 1, Lyon, F-69622, France ;

CNRS, UMR 5023, Laboratoire d'Ecologie des Hydrosystèmes Naturels et Anthropisés,

Villeurbanne, F-69622, France.

${ }^{2}$ CEMAGREF, Laboratoire d'Ecologie Microbienne des Hydrosystèmes Anthropisés, 3 bis

Quai Chauveau, CP 220, 69336 Lyon Cedex 09, France

* Correspondence to:

Arnaud Foulquier

Cemagref, Groupement de Lyon

UR Milieux Aquatiques, Écologie et Pollutions

Laboratoire Écologie Microbienne des Hydrosystèmes Anthropisés

3 bis quai Chauveau

69336 Lyon Cedex 09

FRANCE

Tel : $0033(0) 472208748$

E-mail : arnaud.foulquier@gmail.com 


\section{ABSTRACT}

Groundwaters are increasingly viewed as resource-limited ecosystems in which fluxes of dissolved organic carbon (DOC) from surface water are efficiently mineralized by a consortium of microorganisms which are grazed by invertebrates. We tested for the effect of groundwater recharge on resource supply and trophic interactions by measuring physicochemistry, microbial activity and biomass, structure of bacterial communities and invertebrate density at three sites intensively recharged with surface water. Comparison of measurements made in recharge and control well clusters at each site showed that groundwater recharge significantly increased fluxes of DOC and phosphate, elevated groundwater temperature and diminished dissolved oxygen (DO). Microbial biomass and activity were significantly higher in recharge well clusters but stimulation of autochthonous microorganisms was not associated with a major shift in bacterial community structure. Invertebrate assemblages was not significantly more abundant in recharge well clusters and did not show any relationship with microbial biomass and activity. Microbial communities were bottom-up regulated by DOC and nutrient fluxes but trophic interactions between microorganisms and invertebrates were apparently limited by environmental stresses, particularly DO depletion and groundwater warming. Hydrological connectivity is a key factor regulating the function of DOC-based groundwater food webs as it influences both resource availability for microorganisms and environmental stresses which affect energy transfer to invertebrates and top-down control on microorganisms.

\section{KEY WORDS}

bacterial community structure, crustaceans, denaturing gradient gel electrophoresis, dissolved organic carbon, environmental stress, groundwater recharge, microbial activity, microbial biomass, sediment biofilm, trophic relationships. 


\section{INTRODUCTION}

The relative importance of bottom-up and top-down controls on the structure of communities has long been a matter of intense debates (Oksanen et al. 1981, Hunter and Price 1992, Strong 1992, Polis and Strong 1996). The exploitation ecosystem hypothesis (EEH) predicts that resource availability and predation should alternatively control densities within adjacent trophic levels as food chain length increases with increasing productivity (Oksanen et al. 1981). In the least productive ecosystems, the density of basal species, which is severely constrained by resource availability, cannot support a significant amount of consumers (Menge 2000). In more productive ecosystems, the productivity of basal species increases with elevated resources but their density is kept constant by predation as consumers become more abundant (Steiner 2001). However, a number of biological and environmental factors can affect the predictions of the EEH (Hunter and Price 1992, Leibold et al. 1997, Menge et al. 2002). A shift toward consumer-resistant or less edible species enables a concomitant increase in the density of basal species and consumers along a gradient of increasing productivity (Hunter and Price 1992, Strong 1992, Polis and Strong 1996, Steiner 2001). Reduction of consumer density by environmental disturbances or energy allocation in response to stress can decrease the strength of top-down control on basal species (Menge et al. 2002).

Our present understanding of regulating factors within food webs essentially derives from the study of interactions between photosynthetic producers and herbivores (Hunter and Price 1992, Strong 1992). The strength of bottom-up and top-down forces within detritus-based food webs comparatively have attracted little attention (Mikola and Setälä 1998a, Rosemond et al. 2001), although the latter consume the major proportion of primary production (Moore et al. 2004). Groundwaters provide excellent arenas for testing factors regulating detritus- 
based food webs because they exhibit a reduced diversity of organic matter sources and lack any substantial autotrophic food chains that might interfere with heterotrophic food chains (Huxel and McCann 1998, Simon et al. 2003). In deep water-table aquifers made of unconsolidated sediments (i.e. vadose zone thickness $>2 \mathrm{~m}$ ), dissolved organic matter (DOC) brought by infiltrating water is the main source of organic matter available for groundwater microbial biofilm (Brunke and Gonser 1997, Goldscheider et al. 2006), which represents the basal resource for invertebrate assemblages composed essentially of crustaceans (Ward et al. 1998, Pusch et al. 1998, Simon et al. 2003). Obligate groundwater invertebrates are thought to affect the abundance, activity and composition of microbial communities via their grazing and bioturbation activities (Danielopol 1989, Boulton et al. 2008) although their top-down control on microbial communities has rarely been evaluated (Edler and Dodds 1996). In oligotrophic ecosystems, grazing exerts a major control on microbial biomass whereas in nutrient-rich ecosystems microorganisms can compensate for increased consumer pressure through structural community changes including shifting toward smaller cells and selection of rapidly growing bacteria (Langenheder and Jürgens 2001, Gasol et al. 2002).

Most groundwater ecosystems experiences strong carbon limitation that severely constrains the biomass, activity and composition of microbial communities (Bengtsson 1989, Kazumi and Capone 1994, Baker et al. 2000, Goldscheider 2006). Several studies showed that the productivity and activity of microbial biofilms was distinctly higher in groundwater recharge areas with elevated surface water infiltration rates leading to an increase in DOC supply (Jones et al. 1995, Baker et al. 2000, Craft et al. 2002). Although increased microbial production should theoretically support higher metazoan density, environmental stresses induced by an increase in hydrologic connectivity with surface water might limit trophic interactions between microbial biofilm and invertebrates (Storey and Williams 2004). 
Particularly, groundwater warming caused by increased advective heat transfer from the surface and dissolved oxygen (DO) depletion due to microbial degradation of DOC can alter invertebrate communities (Malard and Hervant 1999, Issartel et al. 2005). Strayer et al. (1997) showed that invertebrate density in the hyporheic zone of several streams in the eastern United States was no longer positively correlated with organic matter content of sediments when DO concentration was $<1 \mathrm{mg} / \mathrm{l} \mathrm{O}_{2}$.

The main objectives of this paper were (1) to determine the responses of sediment biofilm and invertebrate assemblages to increased DOC supply at multiple depths below the groundwater table of an aquifer intentionally recharged with stormwater and (2) to assess the relative contribution of bottom-up and top-down controls in a DOC-based groundwater food web. DOC supply caused by groundwater recharge was expected to stimulate microbial productivity, thereby leading to increased invertebrate density. Dehydrogenase and hydrolytic activities rather than biomass were used as surrogates for microbial productivity because microbial biomass could be kept constant as a result of increased grazing by invertebrates. We first tested for differences in groundwater and sediment physico-chemistry, microbial activity and biomass, structure of bacterial communities and invertebrate density between recharge well clusters located in areas recharged with stormwater and control well clusters located in areas not intentionally recharged with stormwater. Second, we used multi-table analyses for identifying significant links among these four distinct data sets.

\section{STUDY SITE}

The eastern aquifer of the Lyon metropolitan area, France, consists of 3 corridors separated by moraine hills of low hydraulic conductivity $\left(10^{-5}-10^{-8} \mathrm{~m} / \mathrm{s}\right)$ (Datry et al. 2003a; Fig. 1A). Aquifer corridors consist of highly permeable glaciofluvial sediments (hydraulic conductivity: 
$10^{-3}-10^{-2} \mathrm{~m} / \mathrm{s}$ ) and are drained by the Rhône River. The aquifer is intentionally recharged with stormwater at multiple sites to compensate for reduced natural recharge caused by the sealing of urban surfaces. Recharge with stormwater represents at least $10 \%$ of the annual flux of groundwater, which is estimated at 69.1 million $\mathrm{m}^{3}$ (Foulquier et al. 2009). The three selected sites consist of settling and infiltration basins that collect stormwater from residential, commercial and/or industrial areas. The annual groundwater recharge and vadose zone thickness below stormwater infiltration basins ranges from 9.7 to $202.3 \mathrm{~m}^{3}$ of water per $\mathrm{m}^{2}$ and 1.7 to $3.2 \mathrm{~m}$, respectively (Table 1 ).

\section{METHODS}

\section{Site instrumentation}

The three selected sites were instrumented with 6 clusters of 5 wells that were successively positioned at depths of 10,30,50,70 and $90 \mathrm{~cm}$ below the groundwater table (Fig. 1B). At each site, three replicate well clusters were located to intersect the groundwater zone that was not recharged with stormwater and were used as control well clusters. These clusters were located upstream of the stormwater infiltration basins at sites 1 and 2 and laterally for the well cluster at site 3 . Control well clusters were located outside the area of influence of the stormwater plume induced by the infiltration basin. At each site, three other replicate well clusters were located in the immediate downstream vicinity of the basin and were used as recharge well clusters because they intersected the stormwater plume induced by the infiltration basins. Distances between the 3 replicate clusters did not exceed $10 \mathrm{~m}$ and a distance of $0.5 \mathrm{~m}$ separated wells within each replicate cluster. All wells were constructed of $3.8 \mathrm{~cm}$ inner diameter steel pipe with a screen of $13 \mathrm{~cm}$ in height (hole diameter: $0.5 \mathrm{~cm}$ ) at their lower ends. They were installed at the desired depths using a vibrating electric-powered hammer. 


\section{Groundwater, sediment and invertebrates sampling}

Water, sediment and invertebrates were collected once from control and recharge well clusters at the three sites ( $n=90$ samples) to test for the effect of recharge and depth below the groundwater table on (1) DOC concentration, (2) microbial activity and biomass, (3) structure of bacterial communities and (4) invertebrate density. Sampling was carried out over a 10-day period from 10 to 21 September 2006 to enable the measurements of microbiological parameters on freshly-collected sediment samples. However, recharge well clusters were sampled first from 10 to 14 September during a dry-weather period in order to avoid variation in stormwater infiltration rate that could have affected groundwater physico-chemistry. Then, control well clusters were sampled from 17 to 21 September as physico-chemistry of groundwater in areas not intentionally recharged with stormwater was shown to be markedly stable over time (Foulquier et al. 2009). A mixture of water and sediment was extracted using a hand piston pump from each well $(n=90)$. The first $5 \mathrm{~L}$ of water were filtered through a 100$\mu \mathrm{m}$ mesh net and faunal samples were preserved in $4 \%$ formaldehyde. In the laboratory, invertebrates were sorted, counted, and identified to the lowest practical taxonomic level using a dissecting microscope.

Groundwater was collected in 0.1-L burned glass bottles for the determination of DOC and in 1- $\mathrm{L}$ propylene bottles for the analysis of dissolved nutrients $\left(\mathrm{NO}_{3}{ }^{-}, \mathrm{NH}_{4}{ }^{+}\right.$, and $\left.\mathrm{PO}_{4}{ }^{3-}\right)$ and sulphate. Water samples were stored at $4{ }^{\circ} \mathrm{C}$, brought within $4 \mathrm{~h}$ to the laboratory, and filtered through a $0.45 \mu \mathrm{m}$ membrane filter. Dissolved oxygen, $\mathrm{pH}$, temperature and specific conductance were measured in the field using portable meters (WTW OXI 330, WTW pH 330 and WTW LF 330, Weilheim, Germany). Sulphate and specific conductance were used as hydrological tracers to detect inputs of stormwater into groundwater because sulphate concentration and specific conductance of stormwater (ca. $7.6 \pm 4.1 \mathrm{mg} \mathrm{SO}_{4}{ }^{2-}{ }^{-1}, 122 \pm 49 \mu \mathrm{S}$ 
$\mathrm{cm}^{-1}$ ) were much lower than those of groundwater (ca. $55.4 \pm 35.9 \mathrm{mg} \mathrm{SO}_{4}{ }^{2-} \mathrm{1}^{-1},>500 \mu \mathrm{S} \mathrm{cm}^{-}$ $1)$.

At least $0.5 \mathrm{~L}$ of sediment was collected in polypropylene containers that were stored at $\sim 20$ ${ }^{\circ} \mathrm{C}$ and brought within $4 \mathrm{~h}$ to the laboratory. The sediment was sieved wet through a 1-mm sieve before microbiological analyses and analysis of particulate organic carbon (POC), particulate nitrogen (PN) and particulate phosphorus (PP). Sieving enabled the removal of large-size sediment particles which could have biased microbial counts and measurements of microbial activity. About $3 \mathrm{~g}$ of sediment were frozen at $-80{ }^{\circ} \mathrm{C}$ for the analysis of bacterial community structure using denaturing gradient gel electrophoresis (DGGE).

\section{Groundwater and sediment chemical analyses}

The grain size distribution of sediment samples was determined by laser diffraction using a Mastersizer 2000 (Malvern Instruments, Malvern, UK) to check whether differences in microbial activity and biomass between recharge and control well clusters could be accounted for by variation in specific area of sediment. Dissolved organic carbon and POC was determined using a carbon analyzer (multi N / C ${ }^{\circledR} 3100$, Analytik Jena, Jena, Germany) based on thermocatalytic oxidation $\left(850-900{ }^{\circ} \mathrm{C}\right)$ of organic carbon and infrared detection of $\mathrm{CO}_{2}$. The annual flux of DOC reaching the groundwater table at recharge and control well clusters ( $\mathrm{g}$ DOC $\mathrm{m}^{-2} \mathrm{yr}^{-1}$ ) was obtained by multiplying the annual groundwater recharge $\left(\mathrm{m}^{3}\right.$ of water $\mathrm{m}^{-2}$ ) by the average concentration of DOC measured during a recharge event at a depth of 10 $\mathrm{cm}$ below the groundwater table ( $\mathrm{n}=3$ replicate wells per site) obtained in a previous study (Foulquier et al. 2010a). Particulate nitrogen (PN) was analyzed by high-temperature combustion and subsequent measurement of $\mathrm{N}_{2}$ by thermal conductometry (FlashEA 1112, Thermo Electron Corporation, Waltham, MA, USA). Particulate phosphorus (PP) was analyzed by inductively coupled plasma-atomic emission spectrometry after microwave- 
assisted digestion of sediment with $\mathrm{HNO}_{3}$ and $\mathrm{HCl}$. Sulphates and nitrates were determined by ion chromatography. The indophenol-blue and ascorbic acid method were used for the determination of ammonium and phosphate, respectively.

\section{Microbiological analyses}

Foulquier et al. (2011) provided full description of methods used for microbiological analyses. Total number of bacteria was counted using DAPI (4',6-diamidino-2-phenylindol) staining (Porter and Feig 1980). Proteins associated with the aquifer sediment were measured to assess microbial biomass. Measurements were made according to Peterson (1977) using the Sigma Protein Assay Kit P-5656 (Sigma Diagnostics, St. Louis, MO, USA). Carbohydrates were measured on sediment samples using the Dubois method (Dubois et al. 1956). The 2-(piodophenyl)-3-(p-nitrophenyl)-5-phenyl tetrazolium chloride (INT) method was used to measure dehydrogenase activity (respiratory activity) as modified from Houri-Davignon et al. (1989). Hydrolytic activity of biofilm was estimated using the fluorescein diacetate (FDA) hydrolysis method (Jørgensen et al. 1992). Repeated analyses $(n=3)$ of the same sediment sample were carried out for total proteins, carbohydrates and microbial activities. The protein and carbohydrate content per bacterial cell and specific microbial activities (i.e. $\mu$ mol INT and FDA $^{-1}$ cell $^{-1}$ ) were calculated by dividing measurements made on sediments by the number of bacteria. The ratio of protein to carbohydrate $(\mathrm{P} / \mathrm{C}$ ratio) was used to assess whether groundwater recharge influenced the relative production of proteins and carbohydrates by microorganisms.

\section{Bacterial community structure}

$\underline{\text { PCR amplification of 16S rRNA gene fragments }}$ 
Genomic DNA was extracted with a bead procedure using the Fast DNA Spin kit for soil, (MP Biomedicals) according to manufacturer's instructions. The V3 to V5 regions PCR amplification of bacterial 16S rRNA gene was done with $30 \mathrm{ng}$ of template DNA and the primers 358GC including GC clamp and reverse 907rM leading to a 590 bp fragment (Schauer et al. 2000). PCR amplifications were performed on $50 \mu \mathrm{L}$ volumes that contained a 10X Taq reaction buffer (GE Healthcare), $1.5 \mathrm{mM} \mathrm{MgCl} 2,120 \mu \mathrm{M}$ of each deoxynucleotide, 1 $\mu \mathrm{M}$ of each primer, bovine serum albumin (Sigma, $0.5 \mathrm{mg} \mathrm{mL} \mathrm{m}^{-1}$ final concentration), and 1.25 U Taq DNA polymerase (Recombinant Taq DNA polymerase, GE Healthcare). All PCR reactions were performed using a Thermal Cycler T-Personal (Biometra, Germany). For each set of reactions, a negative control, in which the template was replaced by an equivalent volume of sterile deionized water, was included. PCR reactions for 16S rDNA amplification were carried out as described in Schauer et al. (2000). The presence of PCR products of the correct size was confirmed by analyzing $4 \mu \mathrm{L}$ of product on an ethidium-bromide stained $1.2 \%$ (w/vol) agarose gel in $1 \mathrm{X}$ TBE buffer ( $89 \mathrm{mM}$ Tris-base, $89 \mathrm{mM}$ boric acid, $2 \mathrm{mM}$ EDTA, pH 8.0).

\section{Denaturing gradient gel electrophoresis (DGGE)}

DGGE analysis was performed using the CBS-DGGE 2000 system (C.B.S. Scientific Co., Inc.) on 1-mm-thick $6 \%$ polyacrylamide gels (ratio of acrylamide to bisacrylamide was 37.5 : 1) submerged in $1 \mathrm{X}$ TAE buffer $(40 \mathrm{mM}$ Tris acetate $\mathrm{pH} 7.4,20 \mathrm{mM}$ sodium acetate, $1 \mathrm{mM}$ $\mathrm{Na}_{2}$-EDTA). Urea and deionized formamide were used as denaturing agents, and gel gradient ranging from $55 \%$ to $65 \%$ was applied to optimize the separation of PCR-amplified $16 \mathrm{~S}$ rRNA gene fragments $(100 \%$ denaturant contains $7 \mathrm{M}$ urea and 40\% v/v formamide; Dorigo et al. 2006). PCR products were loaded and run at a constant voltage of $100 \mathrm{~V}$ and at a temperature of $60^{\circ} \mathrm{C}$ for about $17 \mathrm{~h}$. A standard reference was loaded on each gel. Separated 
PCR products were stained for $1 \mathrm{~h}$ in the dark with SYBRGold (Invitrogen), visualized on a UV transilluminator (Claravision), and photographed with a camera (Scion Corporation). Digital images of the gel were saved. Image analysis of DGGE gels was performed using the GelCompar II version 4.6 software (Applied Maths, Ghent, Belgium). Sample patterns were normalized with reference profiles included in each gel. A matrix (with samples as rows and 30 DGGE bands as columns) based on the presence (1) or absence (0) of a nucleic acid band at a given height in each lane was constructed. Dissimilarity in DGGE bands was calculated between all pairs of samples using the Dice coefficient (Dice 1945). PCR amplification and DGGE do not necessarily provide an accurate representation of the "true" community structure because these methods only enable to detect predominant species representing $1 \%$ or more of the total community. Moreover, $16 \mathrm{~S}$ rRNA operon heterogeneity can produce multiple DGGE bands for a single organism or results in the co-migration of DNA fragments belonging to different organisms (Wintzingerode et al. 1997, Muyzer and Smalla 1998). However, any methodological biases should have affected all samples equally thereby making their comparison still valid.

\section{Data analysis}

Analyses of variances (ANOVA) were used to test for the effect of groundwater recharge and depth below the groundwater table on groundwater and sediment physico-chemistry, biofilm activity and biomass and invertebrate density. A nested design with recharge nested in sites and depth as main effects was used to avoid confounding between-site variation with variation induced by groundwater recharge. The interactions between depth and recharge nested in sites as well as the interactions between depth and sites were also tested. Post hoc Tukey's tests were performed to determine pairwise differences among sites. A nonparametric multivariate analysis of variance (MANOVA, Anderson 2001) was performed on 
Dice's dissimilarity matrix to determine the amount of variation in bacterial community structure that could be accounted for by the effects of recharge, sites and depth.

Multi-table analyses were performed to examine the links between groundwater and sediment physico-chemistry, microbial activity and biomass, bacterial community structure and invertebrate assemblages using 4 distinct data tables, each table using the same 30 samples as rows (data averaged by replicate well). The physico-chemical and microbiological tables comprised 13 variables (specific area of sediment, specific conductance, $\mathrm{SO}_{4}{ }^{2-}, \mathrm{pH}$, temperature, DO, DOC, POC, $\mathrm{NO}_{3}{ }^{-}, \mathrm{NH}_{4}{ }^{+}, \mathrm{PN}, \mathrm{PO}_{4}{ }^{3-}$ and $\mathrm{PP}$ ) and 5 variables (number of bacteria, protein, carbohydrates, and dehydrogenase and hydrolytic activities) as columns, respectively. The data table describing bacterial community structure was a presence-absence data set for 30 nucleic acid bands revealed by DGGE. The invertebrate data table consisted of the number of individuals per 5-L of pumped water for 6 taxonomic groups (Cyclopoida, Harpacticoida, Ostracoda, Syncarida, Isopoda and Amphipoda).

The relationship between each pair of data sets was measured using the $R v$-coefficient (vectorial correlation coefficient; Robert and Escoufier 1976). The $R v$-coefficient between two tables ranges between 0 and 1 and is a multidimensional equivalent of the ordinary correlation coefficient between two variables. For two given data sets $\mathbf{X}_{k}$ and $\mathbf{X}_{l}$, the $R v$ coefficient writes as follows:

$$
R v\left(\mathbf{X}_{k}, \mathbf{X}_{l}\right)=\frac{\operatorname{Covv}\left(\mathbf{X}_{k}, \mathbf{X}_{l}\right)}{\sqrt{\operatorname{Vav}\left(\mathbf{X}_{k}\right)} \sqrt{\operatorname{Vav}\left(\mathbf{X}_{l}\right)}}
$$

with $\operatorname{Covv}\left(\mathbf{X}_{k}, \mathbf{X}_{l}\right)=\operatorname{Trace}\left(\mathbf{X}_{k}^{t} \mathbf{D}_{n} \mathbf{X}_{l} \mathbf{D}_{p}\right)=\operatorname{Trace}\left(\mathbf{X}_{l}^{t} \mathbf{D}_{n} \mathbf{X}_{k} \mathbf{D}_{p}\right)$ as the vectorial covariance and $\operatorname{Vav}\left(\mathbf{X}_{k}\right)=\operatorname{Trace}\left(\mathbf{X}_{k}^{t} \mathbf{D}_{n} \mathbf{X}_{k} \mathbf{D}_{p}\right)$ and $\operatorname{Vav}\left(\mathbf{X}_{l}\right)=\operatorname{Trace}\left(\mathbf{X}_{l}^{t} \mathbf{D}_{n} \mathbf{X}_{l} \mathbf{D}_{q}\right)$ as the vectorial variance for $\mathbf{X}_{k}$ and $\mathbf{X}_{l}$, respectively; Matrix $\mathbf{D}_{n}$ contains row weights (common to both data sets) and matrices $\mathbf{D}_{p}$ and $\mathbf{D}_{q}$ contain the column weights of $\mathbf{X}_{k}$ and $\mathbf{X}_{l}$, respectively (see Blanc et al. 1998). To test the significance of $R v$-coefficients, rows were randomly permutated within 
tables. Permutations were repeated 1000 times to obtain a null distribution of $R v$-coefficients. We assessed for statistical significance by determining the proportion of null values that were greater than the observed $R v$-coefficients. We also used a procedure proposed by Townsend et al. (2003) to determine the relative importance of any two data sets $\mathbf{X}_{k}$ and $\mathbf{X}_{l}$ in determining a third data set $\mathbf{Y}$. It consists in testing the null hypothesis $R v\left(\mathbf{X}_{k}, \mathbf{Y}\right)=R v\left(\mathbf{X}_{l}, \mathbf{Y}\right)$ against the alternative $R v\left(\mathbf{X}_{k}, \mathbf{Y}\right)>R v\left(\mathbf{X}_{l}, \mathbf{Y}\right)$. Bootstraps are then performed on the statistics $t=R v\left(\mathbf{X}_{k}, \mathbf{Y}\right)-R v\left(\mathbf{X}_{l}, \mathbf{Y}\right)$ using 1000 replicates.

Multiple co-inertia analysis (MCOA; Chessel and Hanafi 1996) was used to provide an ordination of samples along the physico-chemical and biological variables. MCOA is a version of co-inertia analysis (see Dolédec and Chessel 1994, Dray et al. 2003) that was expanded to match more than two data sets. MCOA uses a co-inertia maximization criterion across data sets to provide a sample ordination that summarizes in a common structure the information shared by multiple data sets (see Chessel and Hanafi, 1996 for mathematical details and Bady et al. 2004, Hedde et al. 2005, and Daufresne et al. 2007 for ecological applications). $R v$-coefficients between the data sets and the common structure were calculated to determine the contribution of each data set to the building of the common structure. Samples and variables in each data set were ordered according to their contribution to the common structure along the first axis scores. Multi-table analyses, non-parametric MANOVA and graphical displays were performed using functions in the ade4 (Chessel et al. 2004, Dray et al. 2007) and vegan (Oksanen et al. 2008) packages in R (R Development Core team 2008).

\section{RESULTS}

Response of microbial and invertebrate communities to groundwater recharge

$\underline{\text { Physico-chemistry of groundwater and sediment }}$ 
Input of low-salinity stormwater into groundwater at recharge well clusters resulted in a significant decrease in specific conductance and sulphate concentrations of groundwater (Fig. 2A, Table 2, Supplementary material A). DOC and phosphates were significantly higher in recharge well clusters than in control well clusters and aquifer sediments were significantly enriched in PP and PN. The annual flux of DOC reaching the groundwater table at recharge well clusters was 269,129 , and $14 \mathrm{~g} \mathrm{DOC}^{-2}$ at sites 1,2 , and 3, respectively, whereas it was only about $0.3 \mathrm{~g} \mathrm{DOC}^{-2}$ at control well clusters. Recharge with stormwater significantly elevated groundwater temperature and decreased DO concentration at all sites. Temperature was as high as $22.7^{\circ} \mathrm{C}$ and DO was $<0.5 \mathrm{mg} \mathrm{O}_{2} \mathrm{l}^{-1}$ in recharge well clusters at site 1 with the highest annual recharge rate.

\section{$\underline{\text { Microbial activity and biomass }}$}

Specific surface area of sediment (grain size $<1 \mathrm{~mm}$ ) neither significantly differed between recharge and control well clusters nor between sites. Number of cells, protein content, and global hydrolytic and dehydrogenase activities were significantly higher at recharge well clusters than at control well clusters (Fig. 2B, Table 2). Recharge with stormwater not only increased cell abundance but also enhanced cell physiology because the protein content per cell, and specific bacterial activities and $\mathrm{P} / \mathrm{C}$ ratio were significantly higher at recharge well clusters. All microbial variables except the quantity of carbohydrates and global and specific hydrolytic activities were significantly higher (post-hoc Tukey's tests, $\mathrm{p}<0.05$ ) in recharge well clusters at site 1 receiving the highest annual flux of DOC than in recharge well clusters at site 3 characterized by the lowest DOC flux.

$\underline{\text { Structure of bacterial communities }}$ 
A total of 30 nucleic acid bands was identified and the number of bands averaged $14 \pm 4$ per sample $(n=90)$. Dissimilarity between samples averaged $0.44 \pm 0.09$ and ranged from 0.14 to 0.67. Sites and recharge had a significant effect on bacterial community structures (Supplementary material B). However, the effects of sites and recharge only accounted for $11 \%\left(\mathrm{~F}_{2,58}=5.4, \mathrm{p}=0.001\right)$ and $7 \%\left(\mathrm{~F}_{3,58}=2.4, \mathrm{p}=0.001\right)$ of total variability, respectively.

\section{$\underline{\text { Invertebrate assemblages }}$}

Recharge, sites and depths had no significant effect on invertebrate density (Fig. 2C, Table 2). Cyclopoida was by far the most abundant taxon, representing $80 \%$ of the 1094 individuals collected at all sites. Invertebrate density was only $12 \pm 25$ individuals / $5 \mathrm{~L}$ of pumped water and ranged from 0 to 168 individuals. It was maximal in recharge well clusters at site 2 whereas no invertebrates were collected in recharge well clusters at site 1 that showed the highest annual flux of DOC (Fig. 2C).

\section{Links between environmental attributes, microorganisms, and invertebrates}

The physico-chemical table was significantly correlated $(R v>0.4$, simulated- $p=0.001)$ to the three data tables describing microbial activity and biomass, bacterial community structure and invertebrate assemblages (Fig. 3). Bacterial community structure was significantly correlated to invertebrate assemblages $(R v=0.37$, simulated $-p=0.001)$. However, there was no relationship between invertebrate assemblages and activity and biomass of microbial biofilm $(R v=0.07$, simulated $-p=0.35)$.

Microbial activity and biomass was significantly more correlated to physico-chemistry than to bacterial community structure $\left(R v_{[0.42]}>R v_{[0.24]}\right.$, simulated- $\left.p=0.001\right)$. 
The first and second MCOA axes explained 44 and 16\% of the overall covariance between the 4 data tables, respectively. Sites and treatments (i.e. recharge versus control) were clearly separated along the first two axes of structure common to the 4 data tables (Fig. 4A). $R v$ coefficients between the common structure and individual data tables showed that the variability within each data table was best reproduced in the following order: physicochemistry of groundwater and sediment $(R v=0.83)$, bacterial community structure $(R v=$ $0.68)$, biofilm activity and biomass $(R v=0.55)$ and invertebrate assemblages $(R v=0.52)$.

Loadings of physico-chemical variables along the first axis of the MCOA revealed a gradient of increasing hydrologic connectivity with surface water that was characterized by a decrease in specific conductance, sulphate concentration and DO (positive size of axis 1) and a concomitant increase in $\mathrm{pH}$, temperature, and DOC (from positive to negative side of axis 1) (Fig. 4B but see also supplementary material C). All microbial variables were negatively correlated to axis 1 because aquifer sediment with high microbial activity and biomass typically occurred in low-salinity groundwater, especially in samples collected at site 1. Although a majority of nucleic acid bands appeared in most samples, some bands occurred preferentially in low-salinity groundwater (P064, P101, P180, P313 and P350), whereas others were most frequent in high-salinity groundwater (P481, P527, P816, and P850). The composition of invertebrate assemblages also varied along the hydrologic connectivity gradient with most taxa, except Syncarida, being positively correlated to axis 1 . Higher invertebrate abundances occurred in samples with low values of DOC, temperature and biofilm activity.

\section{DISCUSSION}

Influence of resource supply on groundwater microbial communities 
Our first hypothesis that an increase in DOC fluxes at recharge well clusters would stimulate microbial productivity was supported by our results. Moreover, recharge with surface water increased the supply of phosphates and the particulate stock of phosphorus, which might also have contributed to enhance microbial growth and metabolism (Pace and Cole 1994). Our study adds to an increasing body of literature showing that groundwater microbial communities are bottom-up controlled by the availability of organic carbon and nutrients (e.g. Bengtsson 1989, Kazumi and Capone 1994, Baker et al. 2000). Microbial stimulation was all the more pronounced when the flux of DOC reaching the groundwater table at recharge well clusters was high. The increase in extracellular hydrolytic activity, dehydrogenase activity and microbial biomass (i.e. cell number and protein content) probably reflected the conversion of DOC into low-molecular weight compounds prior to assimilation and subsequent respiration or incorporation into bacterial biomass (Lazarova and Manem 1995, Marmonier et al. 1995). Increased resource supply at recharge well clusters also stimulated cell metabolism because bacteria exhibited higher specific dehydrogenase and hydrolytic activities, elevated protein content per cell and apparently favored the synthesis of proteins rather than the storage of carbon in the form of carbohydrates (Sutherland 2001, MermillodBlondin et al. 2005).

The small proportion in the variability of nucleic acid bands among samples accounted for by recharge suggests that increased resource supply stimulated autochthonous microorganisms without leading to a major shift in bacterial community structure. Moreover, $R v$-coefficients indicated that microbial activity and biomass were mostly related to groundwater physicochemistry rather than to bacterial community structure. Major shifts in the structure of groundwater microbial communities typically occur in organic contaminant plumes along which marked variation in redox potential and concentration of specific organic compounds 
promotes the growth of distinct bacterial strains (Haack and Bekins 2000, Franklin et al. 2000, Röling et al. 2001). Groundwater recharge with stormwater neither markedly increased the biodegradability of DOC leached to groundwater nor did it result in reducing conditions (Eh<100 mV, data not shown). Despite high stormwater infiltration rates, Foulquier et al. (2010a) showed that most of the DOC reaching the groundwater table was refractory because the more labile fraction was intercepted by the soil and vadose zone. Nevertheless, a number of nucleic acid bands occurred preferentially at either ends of the hydrologic connectivity gradient revealed by MCOA. A complementary step of DNA isolation and sequencing would enable identification of whether these particular bands correspond to distinct trophic bacterial groups. For example, it seems that alpha-proteobacteria are prominent in oligotrophic freshwater ecosystems whereas beta-proteobacteria and members of the CytophagaFlavobacterium group are known to be implicated in the degradation of complex recalcitrant organic compounds (Eiler et al. 2003, Gao et al. 2005).

\section{Response of invertebrates to an increase in resource availability}

Our second hypothesis that an increase in microbial productivity would yield higher invertebrate densities was not supported. Energy transfer from biofilm to invertebrates was apparently limited. Invertebrate density was not significantly higher at recharge well clusters and invertebrate assemblages did not significantly correlate $(R v=0.07)$ with microbial activity and biomass. Studies evaluating the relationship between resource supply and groundwater invertebrate assemblages have provided equivocal results with some studies, but not all, reporting a positive relationship between invertebrate density and bacterial abundance (Brunke and Fischer 1999, Franken et al. 2001, Storey and Williams 2004), microbial activity (Mauclaire et al. 2000, Storey and Williams 2004) or dissolved and particulate organic matter (Brunke and Gonser 1999, Datry et al. 2005, Storey and Williams 2004). Mösslacher and 
Notenboom (1999) and Strayer et al. (1997) have pointed out that invertebrate density in groundwater and the hyporheic zone of streams should increase with increasing organic matter supply until DO deficiency resulting from microbial respiration becomes a limiting factor. Similarly, our results suggest that environmental stresses associated with an increase in hydrologic connectivity, particularly DO depletion and excessive heat transfer, offset the beneficial effect of food supply. Indeed, invertebrate assemblages were significantly related to groundwater and sediment physico-chemistry $(R v=0.48)$ while they did not correlate to microbial activity and biomass. Moreover, invertebrates were almost totally absent in groundwater characterized by elevated temperature (i.e. $22^{\circ} \mathrm{C}$ ) and near-anoxic conditions although aquifer sediment supported the highest microbial activity and biomass. Foulquier et al. (2009) showed that advective heat transfer due to stormwater infiltration dramatically increased the annual amplitude of groundwater temperature at recharge well clusters (minimum and maximum temperatures of 8 and $24^{\circ} \mathrm{C}$ ). Summer warming of infiltration beds stimulated aerobic respiration in the soil and vadose zone, thereby leading to groundwater recharge with oxygen-poor stormwater (Datry et al. 2003b, Foulquier et al. 2009). Obligate groundwater animals are typically more resistant to low oxygen concentrations than their epigean relatives, but they cannot survive prolonged anoxic periods (Malard and Hervant 1999). Issartel et al. (2005) measured increased mortality rates in the subterranean amphipods Niphargus rhenorhodanensis and $N$. virei when water temperature exceeded 17 to $21{ }^{\circ} \mathrm{C}$. According to the environmental stress model (Menge and Sutherland 1976, Menge et al. 2002), energy allocation by invertebrates in response to multiple stresses induced by an increase in hydrologic connectivity could have weakened trophic interactions between microorganisms and invertebrates, thereby impeding the flow of energy through groundwater food webs. The environmental stress model may be particularly relevant for understanding the functioning of groundwater DOC-based food webs because labile DOC fluxes are more 
rapidly attenuated at depth into the sediment than environmental disturbances. Datry et al. (2005) and Foulquier et al. (2009) showed that seasonal surface-water temperature fluctuations could be transmitted at depths of several meters below the soil surface at recharge areas whereas considerable attenuation of surface-derived DOC occurred within the first $2 \mathrm{~m}$ of the vadose zone.

\section{Top-down control of microorganisms by invertebrates}

Invertebrates are known to exert a strong control on the productivity and structure of microbial communities in a number of ecosystems including soils (Mikola and Setälä 1998b, Groffman et al. 2004) and streams (Perlmutter and Meyer 1991). Moreover, Edler and Dodds (1996) showed that the subterranean isopod Caecidotea tridentata enhanced by four fold the abundance and activity of attached bacteria in sediments collected from a North American cave. In the present study, low invertebrate density and the potential allocation of energy in response to hypoxia and elevated temperature probably prevented a strong top-down control of groundwater invertebrates on microbial communities. We used values on aquifer microbial productivity and ingestion rate of microbial carbon by copepods found in the literature to assess the potential effect of invertebrate grazing on microbial production at the most densely populated site, which yielded an average of 100 cyclopoid per 51 of pumped water. Assuming a microbial productivity of $0.19 \mathrm{mg} \mathrm{C} \mathrm{dm}^{-3}$ day $^{-1}$ (Craft et al. 2002), an ingestion rate of microbial carbon of $0.47 \mu \mathrm{g} \mathrm{C}$ copepod $^{-1}$ day $^{-1}$ (highest value in Perlmutter and Meyer 1991) and an invertebrate density of 4 cyclopoid per $\mathrm{dm}^{3}$, grazing pressure would at most account for a reduction of only $1 \%$ of microbial production. Foulquier et al. (2010b), who traced the flux of ${ }^{13} \mathrm{C}$-labelled DOC in sediment batches that contained individuals of the subterranean amphipods $N$. rhenorhodanensis, demonstrated that the feeding activity of the amphipods was too low to impede an increase in microbial biomass in response to increasing DOC flux. The 
significant correlation between invertebrate assemblages and bacterial community structure $(R v=0.37)$ may temptingly be considered as evidence for a top-down control by invertebrates. Several studies found that selective grazing by protozoans of cells showing distinct morphology modified the structure of bacterial communities (Šimek et al. 2001, Hahn and Höfle 2001, Rønn et al. 2002). However, the absence of a significant link between invertebrate assemblages and biofilm biomass and activity indicates that the relationship between invertebrate assemblages and bacterial community structure was most likely due to their concomitant correlation to groundwater and sediment physico-chemistry. Indeed, modifications in the structure of planktonic (Hahn and Höfle 2001, Langenheder and Jürgens 2001), soil (Rønn et al. 2002) and benthic (Perlmutter and Meyer 1991) communities of bacteria were always induced by a strong grazing pressure that also affected microbial activity and biomass.

\section{CONCLUSIONS}

Quantifying the strength of trophic interactions within groundwater food webs is a critical step for understanding the influence of microbial communities and invertebrates on biogeochemical processes involved in the $\mathrm{C}$ and $\mathrm{N}$ cycles (Boulton et al. 2008). Although our knowledge of subterranean food webs is still fragmentary, any increase in resource supply is usually expected to stimulate microbial productivity and enhance trophic interactions between microorganisms and invertebrates (Brunke and Fischer 1999, Gibert and Deharveng 2002). Our study revealed a strong bottom-up regulation of attached microbial communities by DOC fluxes in the uppermost layers of groundwater recharged with stormwater, but a weak transfer of energy to the next trophic level composed of crustaceans. Dissolved oxygen depletion and groundwater warming caused by the increase in hydrologic connectivity maintained low invertebrate densities at recharge sites, thereby preventing a significant top-down regulation 
of microbial biomass by invertebrates. Hydrologic connectivity with surface water appears as a key factor setting up the strength of bottom-up and top-down controls through its dual effect on resource supply and environmental conditions. In heavily-recharged groundwater areas, organic carbon processing at the upstream end of DOC-rich groundwater flow paths would essentially be due to microbial activity because environmental stresses severely constrain topdown regulation of micro-organisms by invertebrates. A next important step will be to assess the relative influence of bottom-up and top-down controls within groundwater food webs among aquifers differing in their hydrologic connectivity with surface water.

\section{ACKNOWLEDGMENTS}

This study was conducted within the framework of the experimental Observatory for Urban Hydrology (OTHU, http://www.graie.org/othu/). It was funded by the French National Research Agency (project ANR-05-ECOT-006; http://www.graie.org/ecopluies/), the French programme EC2CO-Cytrix from INSU/CNRS (project "NAPCOD”), the Urban Community of Lyon, and the Rhône-Alpes Region. We are indebted to G. Bouger, E. Malet, Y. Negrutiu, L. Simon, D. Ferreira and F. Vallier for their most dedicated support with the field and laboratory work. We thank two anonymous reviewers for their comments that improved an earlier version of the manuscript.

\section{LITERATURE CITED}

Anderson MJ. 2001. A new method for non-parametric multivariate analysis of variance. Austral Ecology 26: 32-46.

Bady P, Dolédec S, Dumont B, Fruget JF. 2004. Multiple co-inertia analysis: a tool for assessing synchrony in the temporal variability of aquatic communities. Académie des Sciences. Comptes Rendus. Biologies. 327: 29-36. 
Baker MA, Valett HM, Dahm CN. 2000. Organic carbon supply and metabolism in a shallow groundwater ecosystem. Ecology 81: 3133-3148.

Bengtsson G. 1989. Growth and metabolic flexibility in groundwater bacteria. Microbial Ecology 18(3): 235-248.

Boulton AJ, Fenwick GD, Hancock PJ, Harvey MS. 2008. Biodiversity, functional roles and ecosystem services of groundwater invertebrates. Invertebrate Systematics 22: 103116.

Brunke M, Gonser T. 1997. The ecological significance of exchange process between rivers and groundwater. Freshwater Biology 37: 1-33.

Brunke M, Gonser T. 1999. Hyporheic invertebrates - the clinical nature of interstitial communities structured by hydrological exchange and environmental gradients. Journal of the North American Benthological Society 18: 344-362.

Brunke M, Fischer H. 1999. Hyporheic bacteria - relationships to environmental gradients and invertebrates in a prealpine stream. Archiv Fur Hydrobiologie 146: 189-217.

Chessel D, Hanafi M. 1996. Analyse de la co-inertie de K nuages de points. Revue de Statistique Appliquée 44: 35-60.

Chessel D, Dufour AB, Thioulouse J. 2004. The ade4 package-I- One-table methods. R News 4: 5-10.

Craft J, Stanford J, Pusch M. 2002. Microbial respiration within a floodplain aquifer of a large gravel-bed river. Freshwater Biology 47: 251-261.

Danielopol DL. 1989. Groundwater fauna associated with riverine aquifers. Journal of the North American Benthological Society 8: 18-35.

Datry T. 2003a. Urbanisation et qualité des nappes phréatiques: réponse des écosystèmes aquatiques souterrains aux pratiques d'infiltration d'eau pluviale. $\mathrm{PhD}$ thesis. Université Lyon 1, Lyon, France. 
Datry T, Malard F, Vitry L, Hervant F, Gibert J. 2003b. Solute dynamics in the bed of a stormwater infiltration basin. Journal of Hydrology 273: 217-233.

Datry T, Malard F, Gibert J. 2005. Response of invertebrate assemblages to increased groundwater recharge rates in a phreatic aquifer. Journal of the North American Benthological Society 24: 461-477.

Daufresne M, Bady P, Fruget JF. 2007. Impacts of global changes and extreme hydro-climatic events on macroinvertebrate community structures in the French Rhône River. Oecologia 151: 544-559.

Dice LR. 1945. Measures of the amount of ecologic association between species. Ecology 26: 297-302.

Dolédec S, Chessel D. 1994. Co-inertia analysis: an alternative method for studying speciesenvironment relationships. Freshwater Biology 31: 277-293.

Dorigo U, Fontvieille D, Humbert JF. 2006. Spatial variability in the dynamic and the composition of the bacterioplankton community of the Lac du Bourget (France). FEMS Microbiology Ecology 58: 109-119.

Dray S, Chessel D, Thioulouse J. 2003. Co-inertia analysis and the linking of ecological data tables. Ecology 84: 3078-3089.

Dray S, Dufour AB, Chessel D. 2007. The ade4 package-II: Two-table and K-table methods. R News 7: 47-52.

Dubois M, Gilles KA, Hamilton JK, Rebers PA, Smith F. 1956. Colorimetric method for determination of sugars and related substances. Analytical Chemistry 28: 350-356.

Edler CC, Dodds WK. 1996. The ecology of a subterranean isopod, Caecidotea tridentata. Freshwater Biology 35: 249-259. 
Eiler A, Langenheder S, Bertilsson S, Tranvik LJ. 2003. Heterotrophic bacterial growth efficiency and community structure at different natural organic carbon concentrations. Applied and Environmental Microbiology 69: 3701-3709.

Foulquier A, Malard F, Barraud S, Gibert J. 2009. Thermal influence of urban groundwater recharge from stormwater infiltration basins. Hydrological Processes 23: 1701-1713.

Foulquier A, Malard F, Mermillod-Blondin F, Datry T, Simon L, Montuelle B, Gibert J. 2010a. Change in dissolved organic carbon and oxygen at the water table region of an aquifer recharged with stormwater: biological uptake or mixing? Biogeochemistry 99: $31-47$.

Foulquier A, Simon L, Gilbert F, Fourel F, Malard F, Mermillod-Blondin F. 2010b. Relative influences of DOC flux and subterranean fauna on microbial abundance and activity in aquifer sediments: new insights from ${ }^{13} \mathrm{C}$-tracer experiments. Freshwater Biology 55: $1560-1576$.

Foulquier A, Mermillod-Blondin F, Malard F, Gibert J. (2011) Response of sediment biofilm to increased DOC supply in groundwater artificially recharged with stormwater. Journal of Soils and Sediments 11: 382-393.

Franken R, Storey R, Williams D. 2001. Biological, chemical and physical characteristics of downwelling and upwelling zones in the hyporheic zone of a north-temperate stream. Hydrobiologia 444: 183-195.

Franklin RB, Taylor DR, Mills AL. 2000. The distribution of microbial communities in anaerobic and aerobic zones of a shallow coastal plain aquifer. Microbial Ecology 38: 377-386.

Gao XQ, Olapade OA, Leff LG. 2005. Comparison of benthic bacterial community composition in nine streams. Aquatic Microbial Ecology 40: 51-60. 
Gasol JM, Pedros-Alio C, Vaque D. 2002. Regulation of bacterial assemblages in oligotrophic plankton systems: results from experimental and empirical approaches. Antonie Van Leeuwenhoek 81: 435-452.

Gibert J, Deharveng L. 2002. Subterranean ecosystems: a truncated functional biodiversity. Bioscience 52: 473-481.

Goldscheider N, Hunkeler D, Rossi P. 2006. Review: Microbial biocenosis in pristine aquifers and an assessment of investigation methods. Hydrogeology Journal 14: 926-941.

Groffman PM, Bohlen PJ, Fisk MC, Fahey TJ. 2004. Exotic earthworm invasion and microbial biomass in temperate forest soils. Ecosystems 7:45-54.

Haack SK, Bekins BB. 2000. Microbial populations in contaminant plumes. Hydrogeology Journal 8: 63-76.

Hahn MW, Höfle MG. 2001. Grazing of protozoa and its effect on populations of aquatic bacteria. FEMS Microbiology Ecology 35: 113-121.

Hedde M, Lavelle P, Joffre R, Jiménez JJ, Decaëns T. 2005. Specific functional signature in soil macro-invertebrate biostructures. Functional Ecology 19: 785-793.

Houri-Davignon C, Relexans JC, Etcheher H. 1989. Measurements of actual electron transport system (ETS) activity in marine sediments by incubation with INT. Environmental Technology 10: 91-100.

Hunter MD, Price PW. 1992. Playing chutes and ladders: heterogeneity and the relative roles of bottom-up and top-down forces in natural communities. Ecology 73: 724-732.

Huxel GR, McCann K. 1998. Food web stability: the influence of trophic flows across habitats. American Naturalist 152: 460-469.

Issartel J, Hervant F, Voituron Y, Renault D, Vernon P. 2005. Behavioural, ventilatory and respiratory responses of epigean and hypogean crustaceans to different temperatures. 
Comparative Biochemistry and Physiology. Part A, Molecular and Integrative Physiology 141: 1-7.

Jones JB, Fisher SG, Grimm NB. 1995. Vertical hydrological exchange and ecosystem metabolism in a Sonoran Desert stream. Ecology 76: 942-952.

Jørgensen PE, Eriksen T, Jensen BK. 1992. Estimation of viable biomass in wastewater and activated sludge by determination of ATP, oxygen utilization rate and FDA hydrolysis. Water Research 26: 1495-1501.

Kazumi J, Capone DG. 1994. Heterotrophic microbial activity in shallow aquifer sediments of Long Island, New York. Microbial Ecology 28: 19-37.

Langenheder S, Jürgens K. 2001. Regulation of bacterial biomass and community structure by metazoan and protozoan predation. Limnology and Oceanography 46: 121-134.

Lazarova V, Manem J. 1995. Biofilm characterization and activity analysis in water and wastewater treatment. Water Research 29: 2227-2245.

Leibold MA, Chase JM, Shurin JB, Downing AL. 1997. Species turnover and the regulation of trophic structure. Annual Review of Ecology and Systematics 28: 467-494.

Malard F, Hervant F. 1999. Oxygen supply and the adaptations of animals in groundwater. Freshwater Biology 41: 1-30.

Marmonier P, Fontvieille D, Gibert J, Vanek V. 1995. Distribution of dissolved organic carbon and bacteria at the interface between the Rhone River and its alluvial aquifer. Journal of the North American Benthological Society 14: 382-392.

Mauclaire L, Gibert J, Claret C. 2000. Do bacteria and nutrients control faunal assemblages in alluvial aquifers? Archiv Fur Hydrobiologie 148: 85-98.

Menge BA, Sutherland J. 1976. Species diversity gradients: synthesis of the roles of predation, competition and temporal heterogeneity. American Naturalist 110: 351-369. 
Menge BA. 2000. Top-down and bottom-up community regulation in marine rocky intertidal habitats. Journal of Experimental Marine Biology and Ecology 250: 257-289.

Menge BA, Olson AM, Dahlhoff EP. 2002. Environmental stress, bottom-up effects, and community dynamics: Integrating molecular-physiological and ecological approaches. Integrative and Comparative Biology 42: 892-908.

Mermillod-Blondin F, Mauclaire L, Montuelle B. 2005. Use of slow filtration columns to assess oxygen respiration, consumption of dissolved organic carbon, nitrogen transformations, and microbial parameters in hyporheic sediments. Water Research 39: $1687-1698$.

Mikola J, Setälä H. 1998a. No evidence of trophic cascades in an experimental microbialbased soil food web. Ecology 79: 153-164.

Mikola J, Setälä H. 1998b. Productivity and trophic-level biomasses in a microbial-based soil food web. Oikos 82: 158-168.

Moore JC, Berlow EL, Coleman DC, De Ruiter PC, Dong Q, Hastings A, et al. 2004. Detritus, trophic dynamics and biodiversity. Ecology Letters 7: 584-600.

Mösslacher F, Notenboom J. 1999. Groundwater biomonitoring. Biomonitoring of polluted water. Trans Tech Publications, Zürich, Switzerland.

Muyzer M, Smalla K. 1998. Application of denaturing gradient gel electrophoresis (DGGE) and temperature gradient gel electrophoresis (TGGE) in microbial ecology. Antonie van Leeuwenhoek 73: 127-141.

Oksanen L, Fretwell SD, Arruda J, Niemela P. 1981. Exploitation ecosystems in gradients of primary productivity. American Naturalist 118: 240-261.

Oksanen J, Kindt R, Legendre P, O’Hara B, Simpson GL, Stevens MHH, Wagner H. 2008. vegan: community ecology package (http://vegan.r-forge.r-project.org) 
Pace ML, Cole JJ. 1994. Comparative and experimental approaches to top-down and bottomup regulation of bacteria. Microbial Ecology 28: 181-193.

Perlmutter DG, Meyer JL. 1991. The impact of a stream-dwelling harpacticoid copepod upon detritally associated bacteria. Ecology 71: 2170-2180.

Peterson GL. 1977. A modification of the protein assay method of Lowry et al. which is more generally applicable. Analytical Biochemistry 83: 346-356.

Polis GA, Strong DR. 1996. Food web complexity and community dynamics. American Naturalist 147: 813-846.

Porter KS, Feig YS. 1980. The use of DAPI for identifying and counting aquatic microflora. Limnology and Oceanography 25: 943-948.

Pusch M., Fiebig D, Brettar I, Eisenmann H, Ellis BK, Kaplan LA, Lock MA, Naegeli MW, Traunspurger W. 1998. The role of micro-organisms in the ecological connectivity of running waters. Freshwater Biology 40: 453-495.

R Development Core Team. 2006. R: a language and environment for statistical computing. R Foundation for Statistical Computing: Vienna. http://www.R-project.org.

Robert P, Escoufier Y. 1976. A unifying tool for linear multivariate statistical methods: the RV-coefficient. Applied Statistics 25: 257-265.

Röling WFM, Van Breukelen BM, Braster M, Lin B, Van Verseveld HW. 2001. Relationships between microbial community structure and hydrochemistry in a landfill leachate-polluted aquifer. Applied and Environmental Microbiology 67: 4619-4629.

Rønn R, McCaig A, Griffiths B, Prosser J. 2002. Impact of protozoan grazing on bacterial community structure in soil microcosms. Applied and Environmental Microbiology 68: 6094-6105.

Rosemond AD, Pringle CM, Ramirez A, Paul MJ. 2001. A test of top-down and bottom-up control in a detritus-based food web. Ecology 82: 2279-2293. 
Schauer M, Massana R, Pedrós-Alió C. 2000. Spatial differences in bacterioplankton composition along the Catalon coast (NW Mediterranean) assessed by molecular fingerprinting. FEMS Microbiology Ecology 33: 51-59.

Šimek K, Pernthaler J, Weinbauer MG, Hornák K, Dolan JR, Nedoma J, Mašín M, Amann R. 2001. Changes in bacterial community composition and dynamics and viral mortality rates associated with enhanced flagellate grazing in a mesoeutrophic reservoir. Applied and Environmental Microbiology 67: 2723-2733.

Simon KS, Benfield EF, Macko SA. 2003. Food web structure and the role of epilithic biofilms in cave streams. Ecology 84: 2395-2406.

Steiner CF. 2001. The effects of prey heterogeneity and consumer identity on the limitation of trophic-level biomass. Ecology 82: 2495-2506.

Storey RG, Williams DD. 2004. Spatial responses of hyporheic invertebrates to seasonal changes in environmental parameters. Freshwater Biology 49: 1468-1486.

Strayer DL, May SE, Nielsen P, Wolheim W, Hausam S. 1997. Oxygen, organic matter, and sediment granulometry as controls on hyporheic animal communities. Archiv Fur Hydrobiologie 140: 131-144.

Strong DR. 1992. Are trophic cascades all wet? the redundant differentiation in trophic architecture of high diversity ecosystems. Ecology 73: 747-754.

Sutherland IW. 2001. Biofilm exopolysaccharides: a strong and sticky framework. Microbiology 147: 3-9.

Townsend CR, Dolédec S, Norris R, Peacock K, Arbuckle C. 2003. The influence of scale and geography on relationships between stream community composition and landscape variables: description and prediction. Freshwater Biology 48: 768-785. 
Ward JV, Bretschko G, Brunke M, Danielopol D, Gibert J, Gonser T, Hildrew AG. 1998. The boundaries of river systems: the metazoan perspective. Freshwater Biology 40: 531569.

Wintzingerode FV, Göbel UB, Stackebrandt E. 1997. Determination of microbial diversity in environmental samples : pitfalls of PCR-based rRNA analysis. FEMS Microbiology Reviews $21: 213-229$. 
Table 1: Characteristics of the study sites. Annual recharge at recharge well clusters were calculated according to Foulquier et al. (2010a). Recharge at control well clusters was derived only from the natural infiltration of rainwater (i.e. $29 \%$ of annual precipitation).

\begin{tabular}{cccccc}
\hline Site & $\begin{array}{c}\text { Well } \\
\text { cluster }\end{array}$ & $\begin{array}{c}\text { Vadose zone } \\
\text { thickness (m) }\end{array}$ & $\begin{array}{c}\text { Catchment } \\
\text { area (ha) }\end{array}$ & $\begin{array}{c}\text { Basin area } \\
\text { (ha) }\end{array}$ & $\begin{array}{c}\text { Annual } \\
\text { recharge } \\
\left(\mathrm{m}^{3} \mathrm{~m}^{-2}\right)\end{array}$ \\
\hline 1 & Recharge & 3.2 & 270 & 0.39 & $202.3 *$ \\
2 & Recharge & 1.7 & 100 & 0.40 & $73.1 *$ \\
3 & Recharge & 2.8 & 2.5 & 0.08 & $9.7 *$ \\
1 & Control & 3.5 & & & 0.24 \\
2 & Control & 2.4 & & & 0.24 \\
3 & Control & 4.2 & & & 0.24 \\
\hline
\end{tabular}

* annual precipitation $\times$ runoff coefficient on urban catchment $\times$ catchment area of the infiltration basin / surface area of the infiltration basin 
Table 2: Results of nested analysis of variance for testing the effect of recharge and depth below the groundwater table on groundwater physico-chemistry, biofilm biomass and activity and invertebrate density. The term recharge(site) means that the recharge factor is nested within the site factor.

\begin{tabular}{|c|c|c|c|c|c|c|c|c|c|c|}
\hline & \multicolumn{2}{|c|}{ Recharge(Site) } & \multicolumn{2}{|c|}{ Site } & \multicolumn{2}{|c|}{ Depth } & \multicolumn{2}{|c|}{ Site $x$ Depth } & \multicolumn{2}{|c|}{$\begin{array}{c}\text { Recharge(Site) } \\
\text { x Depth }\end{array}$} \\
\hline & $\mathrm{F}_{3,12}$ & $p$ & $\mathrm{~F}_{2,3}$ & $p$ & $\mathrm{~F}_{4,8}$ & $p$ & $\mathrm{~F}_{8,12}$ & $p$ & $\mathrm{~F}_{12,60}$ & $p$ \\
\hline DOC & 6.89 & 0.006 & 9.76 & 0.062 & 4.85 & 0.028 & 0.56 & 0.792 & 1.21 & 0.297 \\
\hline DO & 63.86 & $<0.001$ & 0.17 & 0.851 & 0.48 & 0.749 & 1.13 & 0.408 & 1.87 & 0.057 \\
\hline Temperature & 562.35 & $<0.001$ & 0.23 & 0.810 & 6.47 & 0.013 & 1.27 & 0.344 & 0.80 & 0.652 \\
\hline Specific conductance & 43.42 & $<0.001$ & 6.40 & 0.081 & 4.10 & 0.043 & 1.31 & 0.323 & 0.80 & 0.650 \\
\hline $\mathrm{pH}$ & 14.35 & $<0.001$ & 7.64 & 0.059 & 2.01 & 0.186 & 1.67 & 0.204 & 0.81 & 0.636 \\
\hline $\mathrm{NO}_{3}^{-}$ & 13.49 & $<0.001$ & 1.49 & 0.353 & 5.01 & 0.026 & 1.20 & 0.376 & 1.34 & 0.223 \\
\hline $\mathrm{NH}_{4}^{+}$ & 3.82 & 0.039 & 1.00 & 0.488 & 2.24 & 0.154 & 0.53 & 0.816 & 0.73 & 0.721 \\
\hline $\mathrm{SO}_{4}^{2-}$ & 18.18 & $<0.001$ & 9.53 & 0.045 & 1.64 & 0.256 & 1.68 & 0.202 & 0.61 & 0.822 \\
\hline $\mathrm{PO}_{4}^{3-}$ & 28.58 & $<0.001$ & 0.89 & 0.498 & 0.29 & 0.877 & 0.99 & 0.490 & 0.91 & 0.541 \\
\hline POC & 1.64 & 0.233 & 1.61 & 0.297 & 0.05 & 0.994 & 1.91 & 0.151 & 1.59 & 0.120 \\
\hline PN & 8.81 & 0.002 & 1.81 & 0.302 & 0.97 & 0.474 & 1.16 & 0.393 & 1.78 & 0.073 \\
\hline PP & 17.30 & $<0.001$ & 0.85 & 0.508 & 2.47 & 0.129 & 1.25 & 0.351 & 2.03 & 0.037 \\
\hline Specific surface area & 0.41 & 0.748 & 6.93 & 0.075 & 2.68 & 0.110 & 0.53 & 0.811 & 3.12 & 0.002 \\
\hline Number of bacteria & 38.45 & $<0.001$ & 0.53 & 0.636 & 0.66 & 0.639 & 1.48 & 0.261 & 0.28 & 0.991 \\
\hline Proteins & 12.11 & 0.001 & 1.00 & 0.456 & 1.03 & 0.450 & 1.72 & 0.192 & 1.73 & 0.083 \\
\hline Carbohydrates & 2.16 & 0.145 & 1.08 & 0.434 & 0.39 & 0.810 & 1.34 & 0.311 & 2.44 & 0.012 \\
\hline Hydrolytic activity & 5.54 & 0.013 & 0.25 & 0.798 & 1.57 & 0.273 & 0.74 & 0.660 & 2.81 & 0.004 \\
\hline Dehydrogenase activity & 41.35 & $<0.001$ & 0.75 & 0.542 & 4.06 & 0.044 & 1.45 & 0.271 & 1.03 & 0.438 \\
\hline Protein content per cell & 11.05 & 0.001 & 0.94 & 0.471 & 1.03 & 0.450 & 1.83 & 0.167 & 1.80 & 0.068 \\
\hline $\mathrm{P} / \mathrm{C}$ ratio & 18.69 & $<0.001$ & 2.76 & 0.209 & 3.80 & 0.051 & 0.99 & 0.486 & 1.65 & 0.103 \\
\hline Sp. hydrolytic activity & 6.72 & 0.007 & 0.18 & 0.841 & 1.48 & 0.294 & 0.66 & 0.717 & 2.39 & 0.013 \\
\hline Sp. dehydrogenase activity & 46.62 & $<0.001$ & 0.88 & 0.500 & 3.61 & 0.058 & 1.63 & 0.216 & 0.90 & 0.555 \\
\hline Invertebrate density & 1.68 & 0.224 & 7.84 & 0.183 & 1.20 & 0.380 & 0.51 & 0.829 & 1.78 & 0.073 \\
\hline
\end{tabular}


Figure 1: A. Locations of recharge (R) and control (C) well clusters at the 3 study sites in the eastern aquifer of the Lyon metropolitan area, France. B. Cross sectional illustration of recharge and control replicate well clusters.

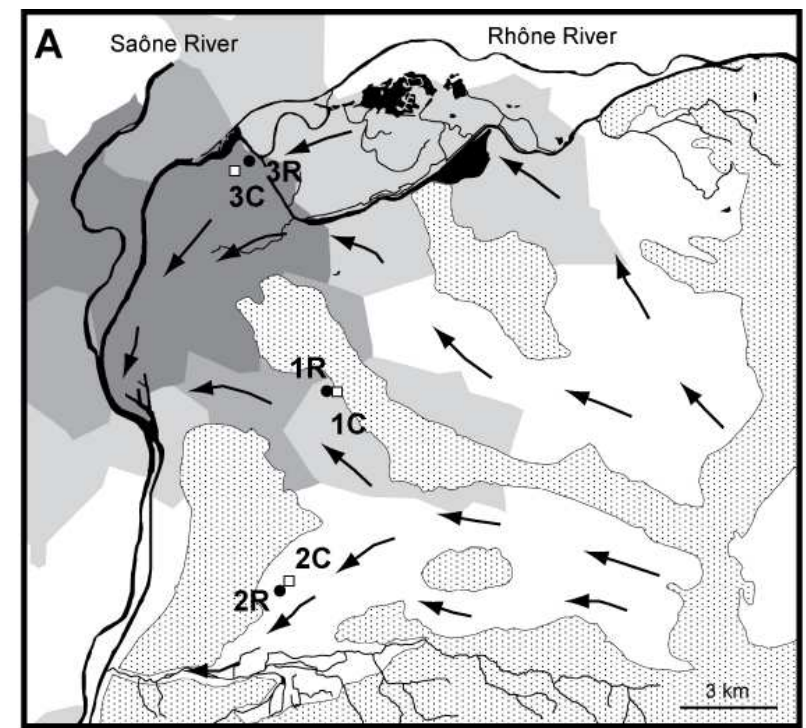

B

Control well

Recharge well

clusters $(\times 3)$ clusters $(\times 3)$

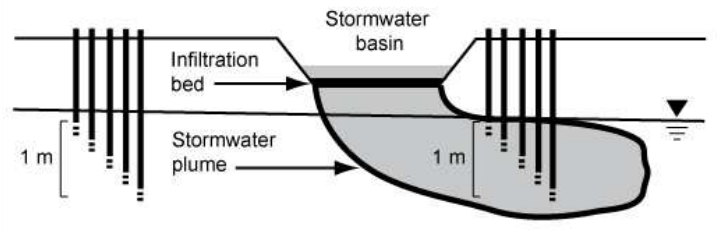

Population density (inhabitants $/ \mathrm{km}^{2}$ )

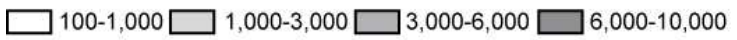

Moraine hill (glacial till)

$\longrightarrow$ Groundwater flow direction

- Recharge replicate well clusters (R)

$\square$ Control replicate well clusters (C) 
Figure 2: Variation of (A) specific conductance, dissolved organic carbon (DOC), dissolved oxygen (DO) and temperature, (B) microbial parameters and (C) invertebrate density at various depths below the groundwater table for control (white square) and recharge (black circles) wells at sites 1 to 3 . Horizontal bars show \pm 1 standard deviation for 3 replicate wells. 
Sp. conductance

A

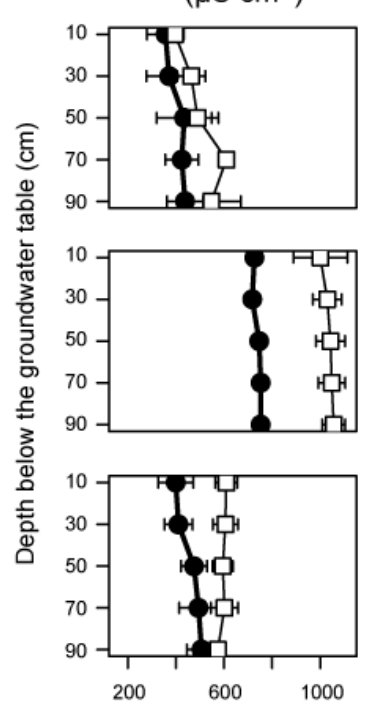

Number of bacteria

$\mathbf{B}$

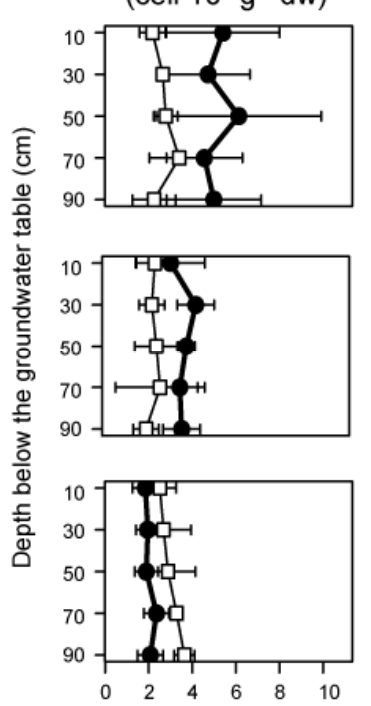

Hydrolytic activity $\left(10^{-3} \mu \mathrm{mol} \mathrm{h}{ }^{-1} \mathrm{~g}^{-1} \mathrm{dw}\right)$

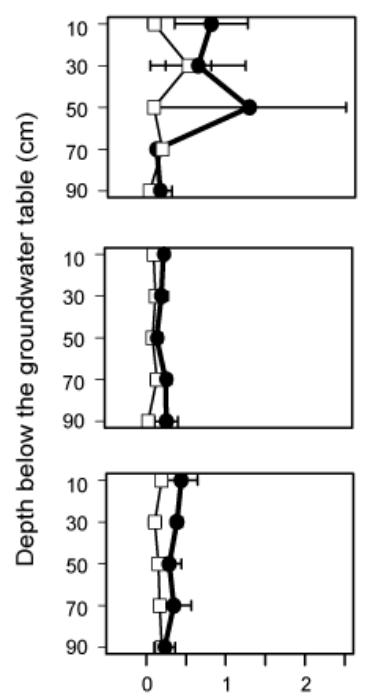

DOC

(mg r-1)
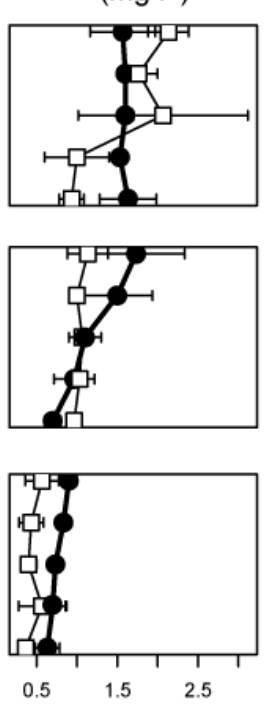

Proteins $\left(\mathrm{mg} \mathrm{g}^{-1} \mathrm{dw}\right)$
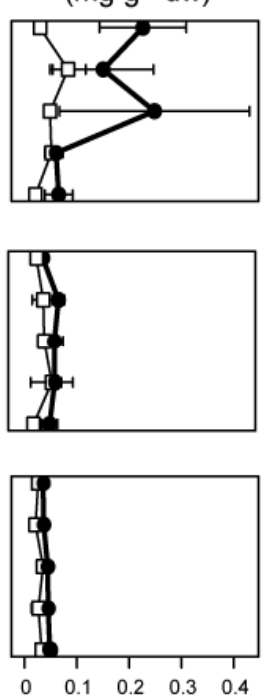

DO
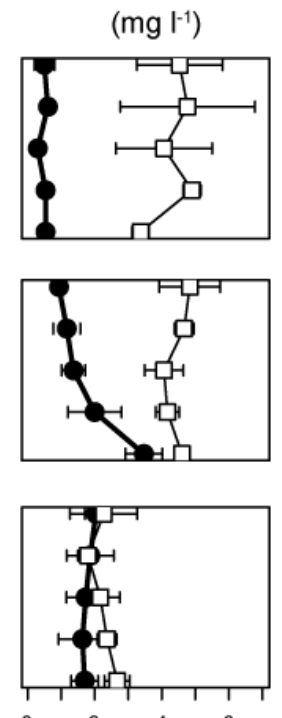

Carbohydrates $\left(\mathrm{mg} \mathrm{g}^{-1} \mathrm{dw}\right.$ )
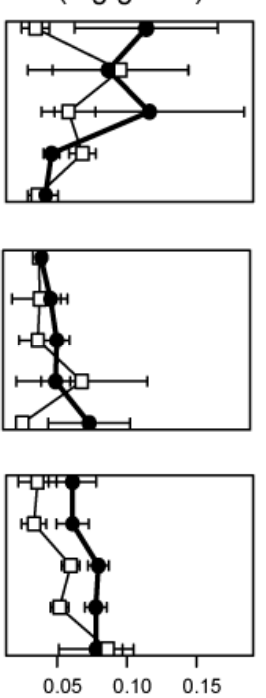

Temperature $\left({ }^{\circ} \mathrm{C}\right)$

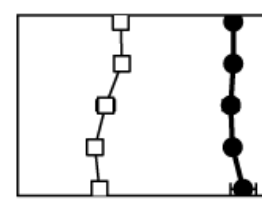

Site 1

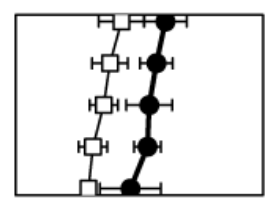

Site 2

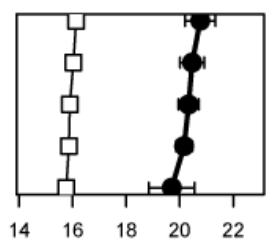

Site 3

Proteins/ Carbohydrates

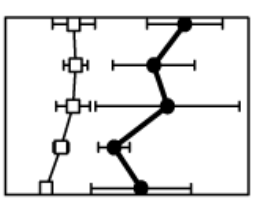

Site 1

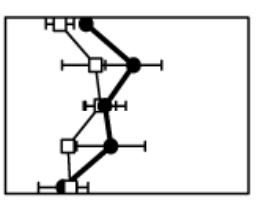

Site 2

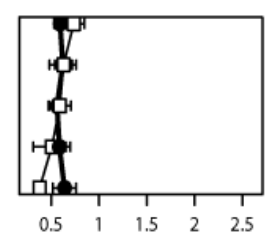

Site 3
Dehydrogenase activity
$\left(10^{-3} \mu \mathrm{mol} \mathrm{h} \mathrm{h}^{-1} \mathrm{~g}^{-1} \mathrm{dw}\right)$
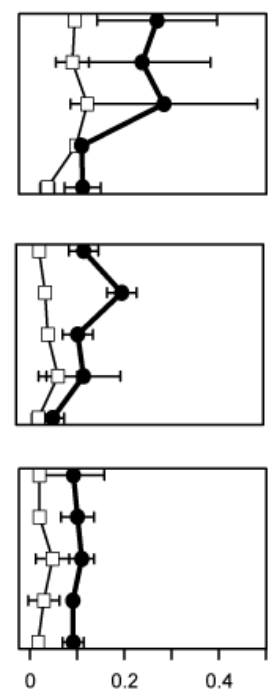

$\log 10$ (invertebrate density +1 )

C

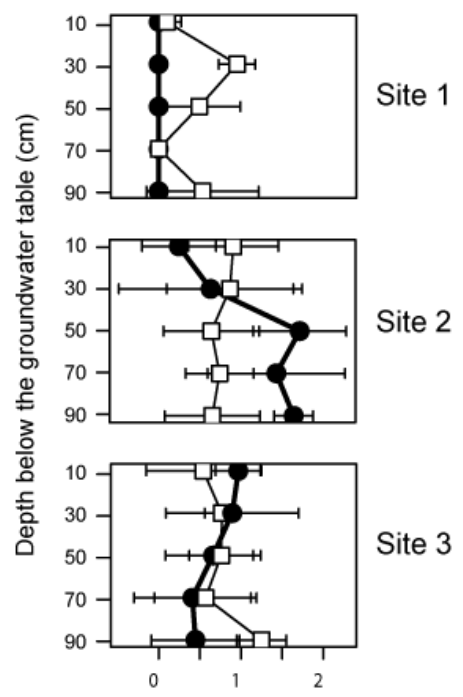


Figure 3: Synthesis of the relationships between the four data sets showing $R v$-coefficients with simulated-p values (broken line: non significant correlation).

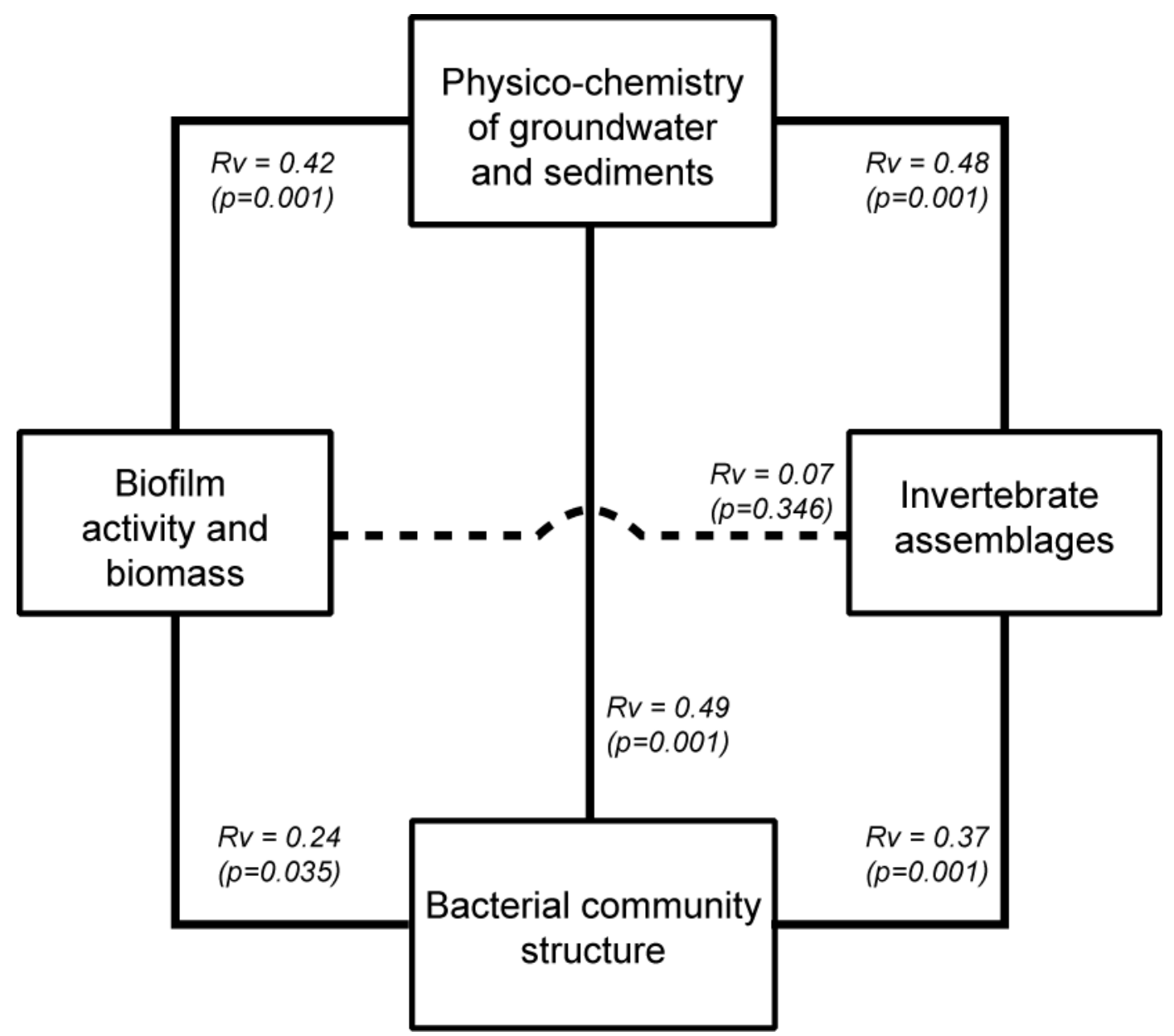


Figure 4: Results of MCOA performed on physico-chemistry of groundwater and sediment, biofilm activity and biomass, bacterial community structure and invertebrate assemblages. A. Sample scores (dots) on the first two MCOA axes. Control and recharge well clusters at each site are positioned at the average of their samples ( $n=5$ depths averaged by replicate well). Lines link samples to the corresponding well clusters. B. Loadings for physico-chemical and microbiological variables, nucleic acid bands, and invertebrate taxa on the first two axes of the common structure. The length of arrows is proportional to the contribution of a given variable to the common structure. 


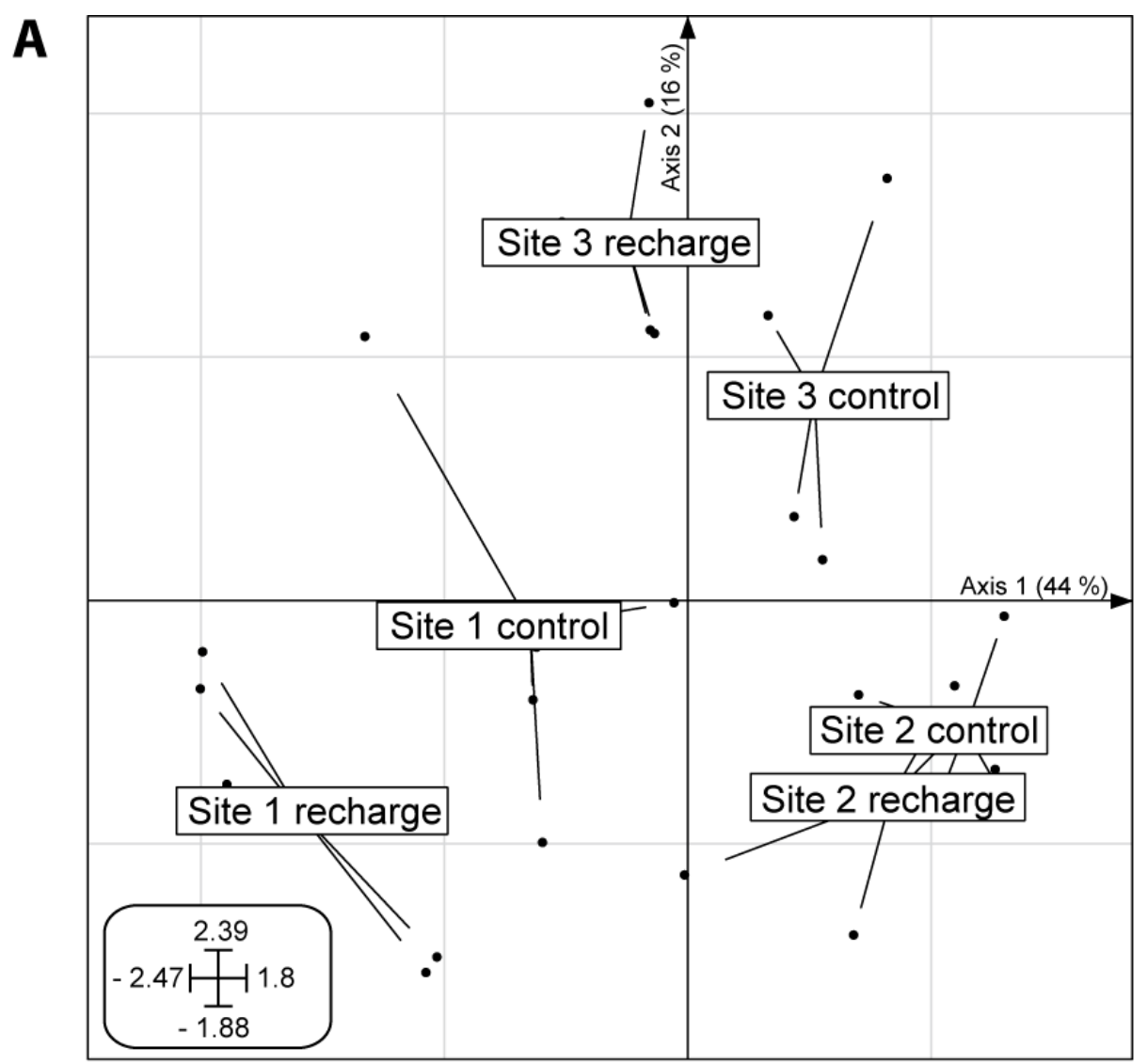

B
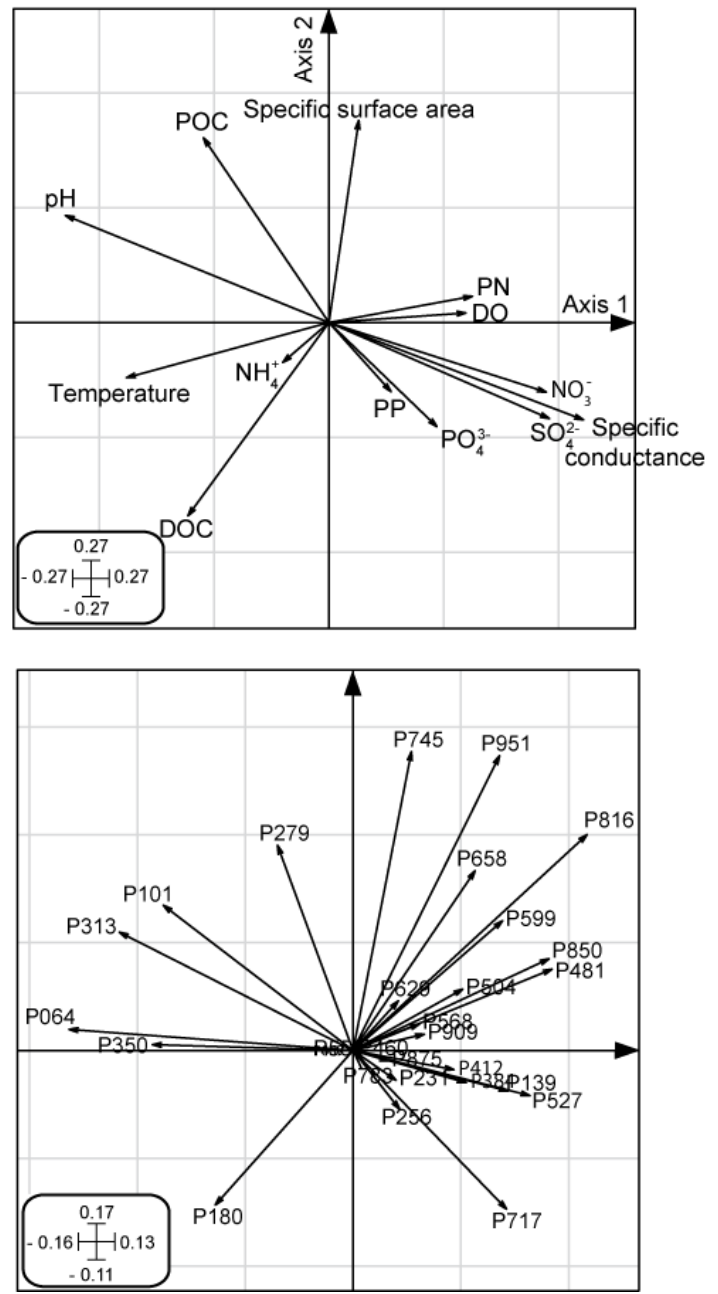
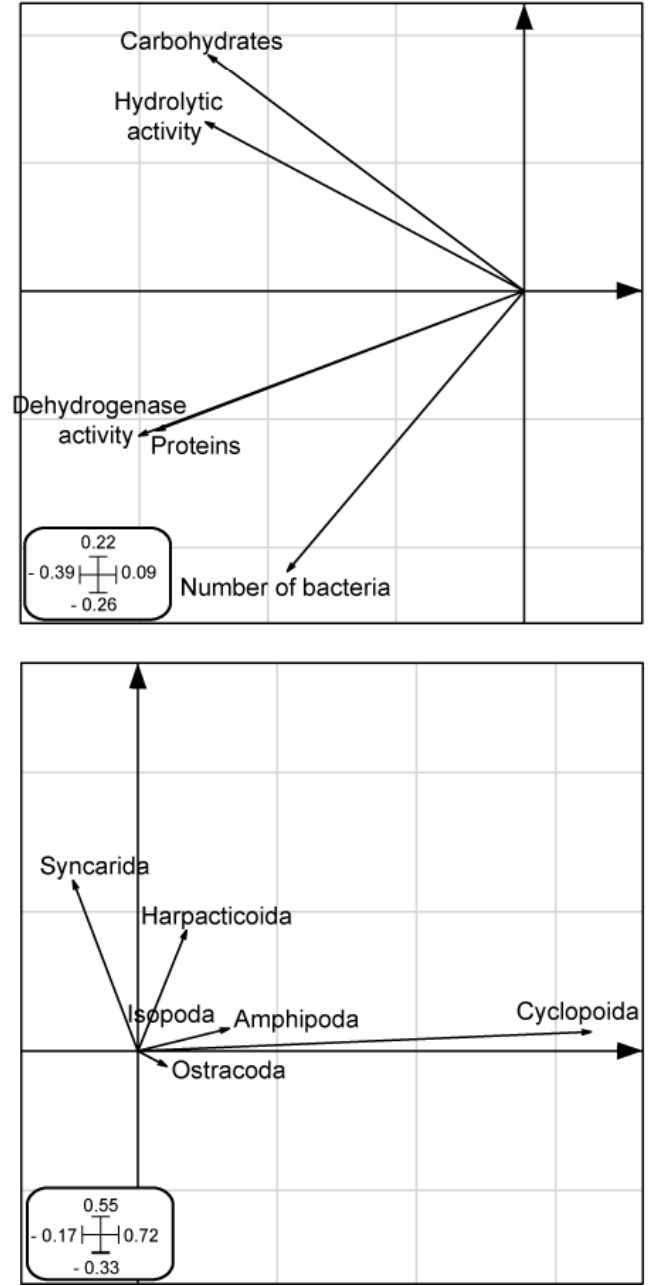
Author-produced version of the article published in Ecosystems (2011), vol. 14, Iss. 8 , pp 1339-1353

The original publication is available at http://link.springer.com/ doi : 10.1007/s10021-011-9484-0 